Jpn. J. Oral Biol., 33 : 305-314, 1991.

\title{
ORIGINAL
}

\section{Effects of methylprednisolone sodium succinate on the growth of hard tissues in the young rat}

\author{
Hiroshi Takagi, Kazuhide Kobayashi and Yuzo Kato* \\ Department of Orthodontics \\ (Chief : Prof. Kazuhide Kobayashi) \\ ${ }^{*}$ Department of Pharmacology \\ (Chief : Prof. Yuzo Kato) \\ Nagasaki University School of Dentistry, 7-1 \\ Sakamoto-machi, Nagasaki 852 Japan \\ [Accepted for publication: February 8, 1991]
}

Key words : Methylprednisolone/weight loss/bone growth/alternate-day administration / osteoporosis

\begin{abstract}
The present study was performed to obtain direct evidence of MPNSS (methylprednisolone sodium succinate) on the growth retardation of hard tissues in rats. For this purpose, different doses of MPNSS were injected intraperitoneally to the rat (daily administration of $2.0 \mathrm{mg} / \mathrm{kg}, 14$ times and alternate-day administration of $10.0 \mathrm{mg} / \mathrm{kg}, 14$ times). To the age-matched control animals, $0.9 \% \mathrm{NaCl}$ solution was injected. The body weight was measured daily. Wet weight of the adrenal gland was measured and the lengths of upper jaw (diastema) and tibia were also measured with dial calipers. In addition, the rate of the incisal dentine formation was measured with a chronological-labelling method using tetracycline. The right tibia was used for measuring the defatted-dry weight and the ash weight. To detect changes in calcium homeostasis, contents of calcium and phosphorus in the plasma were analysed. Following treatment with MPNSS, the weight loss, atrophy of the adrenal gland and retardation of bone growth were detected in both experimental groups. On the other hand, osteoporosis could not be recognized by contact-microradiography. It was confirmed that reduction of the growth rates was greater in the daily injected group than in the alternate-day injected one. In conclusion, the present study showed a direct inhibitory effect of MPNSS on bone growth in growing young rats. It is sug. gested that a larger dose of glucocorticoids could be given more effectively with less side effects of the drug by an alternate-day administration.
\end{abstract}

\section{Introduction}

Pharmacological effects of glucocorticoids (GCs) are numerous and widespread ${ }^{11}$. While GCs have very useful clinical applications, adverse effects of GCs include the numerous and diverse manifestations of Cushing's syndrome and of hypothalamic-pituitary-adrenal (HPA) suppressions ${ }^{2,3}$.

One of the side effects of GCs is osteoporosis $^{4,5)}$ observed in both human ${ }^{6,7)}$ and experimental animals ${ }^{8}$. The induction mechanisms of GC-osteoporosis are not yet clear, however, it may be due in part to the disturbance of calcium metabolism $\left.{ }^{4}, 5\right)$ and also to that of bone formation and resorption ${ }^{9,10}$.

In addition, the growth retardation accompanied by a marked dose-related inhibition of the increment of body weight ${ }^{11}$ ' has been reported in both human children ${ }^{12-14}$ and young growing animals ${ }^{15-21)}$ following a long term administration of high-doses of GCs.

Methylprednisolone sodium succinate (MP. NSS) is one of short-acting and injection-typed 
GCs. Although MPNSS has widely been used for clinical treatments, it is very difficult to judge the direct evidence of the side effects by the drug in previous studies. Most of the side effects of MPNSS described in the literature seems to be based on findings using different types of GCs besides MPNSS. Sheagren et al..$^{22}$ have demonstrated the retardation of bone growth following successive administrations of MPNSS to the rabbit. However, it is not known whether a similar effect could be seen by MPNSS to the other experimental animals such as rats. It is known that a drug could induce different kinds of pharmacological effects to different kinds of animals. Since the rat is one of the most widely used experimental animals, it would be worthwhile to obtain the basic data on the side effects of MPNSS on the hard tissues of this animal.

The main purpose of the present study was to examine whether MPNSS has direct effects on the growth retardation of the different types of hard tissues in association with the inhibition of the linear growth of body weight in rats. Therefore, the length between two anatomically discernible points of the upper jaw (diastema), tibia or mandible was measured for the evaluation of the bone growth 18-21). In addition, biochemical analyses of bone and serum and contact microradiographic observations of hard tissues were performed to see the effects of GC on the bone metabolism.

\section{Materials and Methods}

Male rats of the Sprague-Dawley (SD) strain weighing about $120 \mathrm{~g}$ were used. In general, animals were housed in metal cages (4 rats to a cage) under a $12 \mathrm{hr}$ light and dark cycle for at least 5 days prior to use. They were given a standard diet (MF, Oriental Yeast Co. Ltd., Tokyo, Japan) and tap water ad libitum. Their body weights were measured daily. During the experimental period, the room temperature was kept at $22{ }^{\circ} \mathrm{C}$ to $24^{\circ} \mathrm{C}$ and the relative humidity, 55 to $75 \%$.

The dose of the drug (MPNSS) is represented as that of methyloprednisolone contained in the commercially available form of the drug.

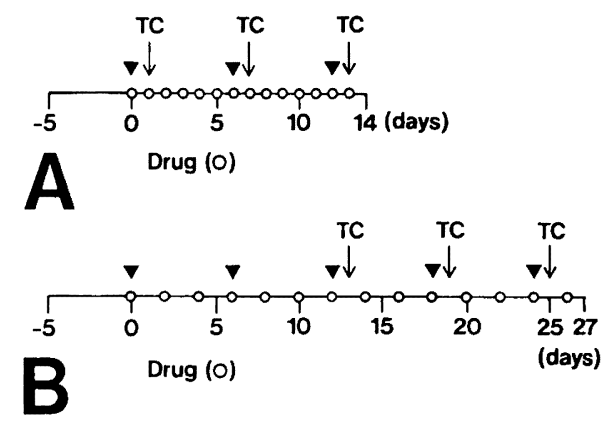

Fig. 1 Experimental schedule for MPNSS administration. A : Daily injections of MPNSS $(2.0 \mathrm{mg} / \mathrm{kg}$, i.p., 14 times), Control $(0.9 \% \mathrm{NaCl}$ solution, i. p., 14 times). B: Alternate-day injections of MPNSS $(10.0 \mathrm{mg} / \mathrm{kg}$, i. p., 14 times), Control $(0.9 \% \mathrm{NaCl}$ solution, i. p. 14 times). Open circles indicate the injection times of MPNSS or $\mathrm{NaCl}$ solution. Arrows indicate the injection times of TC (tetracycline Hydrochloride). Arrow heads indicate the blood-collecting times.

\section{Schedule of the animal experiments}

In the first experiment, 20 rats were divided into 2 equal groups. In one group of rats (experimental group), MPNSS (Upjohn Co. Ltd., USA, $2.0 \mathrm{mg} / \mathrm{kg}$ body weight) was injected daily (14 times) intraperitoneally as shown in Fig. 1-A. In the other group of rats (control group), same volume $(2 \mathrm{ml} / \mathrm{kg})$ of $0.9 \% \mathrm{NaCl}$ solution was injected. In both groups, TC (tetracycline hydrochloride, $6.67 \mathrm{mg} / \mathrm{kg}$ body weight) was injected intraperitoneally 3 times on the $1 \mathrm{st}, 7$ th and 13 th days of the experimental period for chronological labelling of growing hard tissues. On the scheduled time $(0,6$ th 12 th days $)$ dur. ing the experimental period, about $120 \mu l$ of the blood was collected in a heparinized glass tube from the tail vein for the analyses of plasma concentrations of calcium and inorganic phosphorus. Injections of the drug and collections of the blood sample were made between $1: 00$ and $2: 00$ p. m. to minimize changes due to diurnal fluctuations ${ }^{23)}$.

In the second experiment, the effects of alternate-day administration of the same drug on the growth of hard tissues were examined. Twenty rats were also divided into 2 equal groups. MPNSS ( $10.0 \mathrm{mg} / \mathrm{kg}$ body weight) 


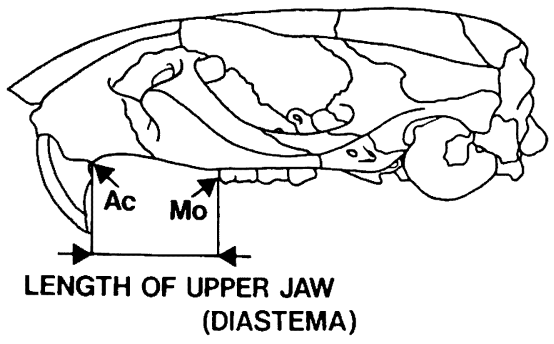

Fig. 2 Schematic illustration of the skull showing reference points used for the measurement of the upper jaw. The distance between the point $\mathrm{Ac}$ and the point Mo was measured as an indicator to determine the growth of the upper jaw. Ac: The alveolar crest on the concave side of the incisor. Mo: The most anterior point of the crown of the first molar.

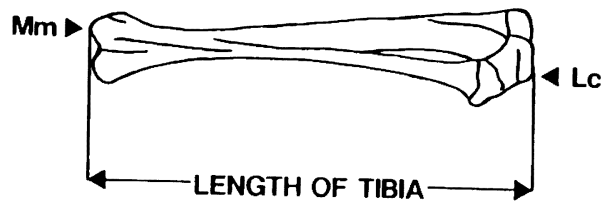

Fig. 3 Schematic illustration of the tibia showing the site of measurement. $\mathrm{Mm}$ : Medial malleolus of distal diaphysis. Lc: Lateral condyle of proximal diaphysis.

was injected every other day (14 times) intraperitoneally as shown in Fig. 1-B (experimental group). $\mathrm{NaCl}$ solution was also injected to the control animals. TC was injected on the 13 th, 19 th and 25 th days of the experimental period.

As the untreated normal controls, 8 other rats were killed on day 0 .

\section{Sample preparation}

One day after the last injection, animals were killed by decapitation under ether anesthesia. Wet weight of the adrenal gland was measured. The skull, tibia and mandible were excised, removed of adherent soft tissues and fixed in $10 \%$ neutral formalin. These specimens were processed for the measurements of hard tissue growth using the methods previously described by Yamada ${ }^{24)}$ as follows : After fixation, the skull was sagittally halved along the midline with a single-edged safty razor blade. To take a standardized photograph, only one side of the skull sample was placed on the central region under the radiation field and the cutting plane was set in close contact with the surface of an X-ray film cassette. On the other hand, each sample of the tibia was fixed in the same position tightly with an adhesive tape since it was unable to keep the sample in contact closely with the surface of the cassette.

The right halves of the skulls and the right tibiae were radiographed by using a soft X-ray apparatus (Type-CMS, Softex Co. Ltd., Japan). The radiographs were taken at a setting of $30 \mathrm{kV}, 3 \mathrm{~mA}$ and $150 \mathrm{sec}$ using Fuji X-ray Film (Type-FR, Fuji Photo Film Co. Ltd., Japan) and developed for $5 \mathrm{~min}$ (Superdol, Fuji Photo Film Co. Ltd., Japan) at $20^{\circ} \mathrm{C}$. Then, the radiographs were printed on photographic paper by a contact method.

Measurements of the lengths of bones were carried out 10 times at each site on the image of the specimen on the photographic paper using dial calipers (Mitutoyo, Co. Ltd., Tokyo) with a minimum graduation of $0.02 \mathrm{~mm}$ and the average value was used. Reference points employed in the measurement of the upper jaw are shown in Fig. 2. The distance between the two reference points (AcMo) was measured as an indicator to determine the growth of the upper jaw. The length (Ac-Mo) almost corresponds to the diastema which is the space between the first molar and the incisor ${ }^{24}$. The distance between the proximal and distal epiphysis of the tibia was measured along its central axis (Fig. 3); this was regarded as the length of the tibia.

After recording the pictures, the right tibiae were defatted in a mixture of trichloroethylene and methanol $(1: 1)$ for 3 days, dried at $110^{\circ} \mathrm{C}$ for 2 days and ashed in an electric furnace at $700{ }^{\circ} \mathrm{C}$ for $7 \mathrm{hrs}$. Both defatted dry weight (D. D. W.) and ash weight (Ash) were used for the calculation of the ratio of bone components (Ash/D. D. W.).

For contact microradiography (CMR), the left tibiae were dehydrated in ethanol and embedded in polyester resin (Rigolac, Nissin EM Co. Ltd., Japan). Thick sections (about 300 $\mu \mathrm{m})$ were cut through the mid-sagittal plane of the proximal part of tibiae using a lowspeed cutting machine (Isomet; Buehler, Co. 


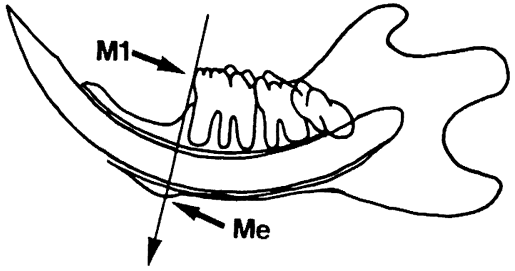

Fig. 4 Schematic illustration of the mandible. A long arrow indicates the direction of sectionning. M 1: Mesial surface of the first molar. Me : Menton.

Ltd., USA) and then the ground sections, 60 $\mu \mathrm{m}$ in thickness, were obtained by manual grinding. To observe changes in the trabecular bone, the contact microradiograms were obtained by using a constant potential generator (PW 1729 type, Philips Co. Ltd., USA). The pictures were taken under the conditions of $20 \mathrm{kV}, 20 \mathrm{~mA}$ and $6 \mathrm{~min}$ using Kodak Spectroscopic Saftety Film (Kodak Co. Ltd., USA) and developed for $5 \mathrm{~min}$ at $20^{\circ} \mathrm{C}$ in Kodak D.19 developer and examined with a light microscope.

Using the same technique, mandibles including teeth were embedded in polyester resin, cut transversely through a plane at the mesial side of the first molar (Fig. 4), and ground sections about $60 \mu \mathrm{m}$ in thickness were obtained. Each section was examined with a fluorescent microscope (BH 2-RFK, Olympus Co. Ltd., Japan) to observe the chronologically labelled tetracycline lines in the hard tissues. The rates of dentine formation in the incisor were estimated by measuring the distances between two labelled lines ${ }^{25}$.

Chemical analyses

Total calcium content in plasma was measured by an atomic absorption spectrophotometer $^{26)}$. The inorganic phosphorus content was measured by an ascorbic acid method ${ }^{27}$.

Statistical analyses were performed using Student's t-test.

\section{Results}

Changes in the body weight in the control and MPNSS-injected groups are shown in Fig. 5. In the daily-injection-group $(2.0 \mathrm{mg} /$ $\mathrm{kg}$, i. p.), the increment of the body weight was markedly reduced throughout the experimental period and the weight gain per day
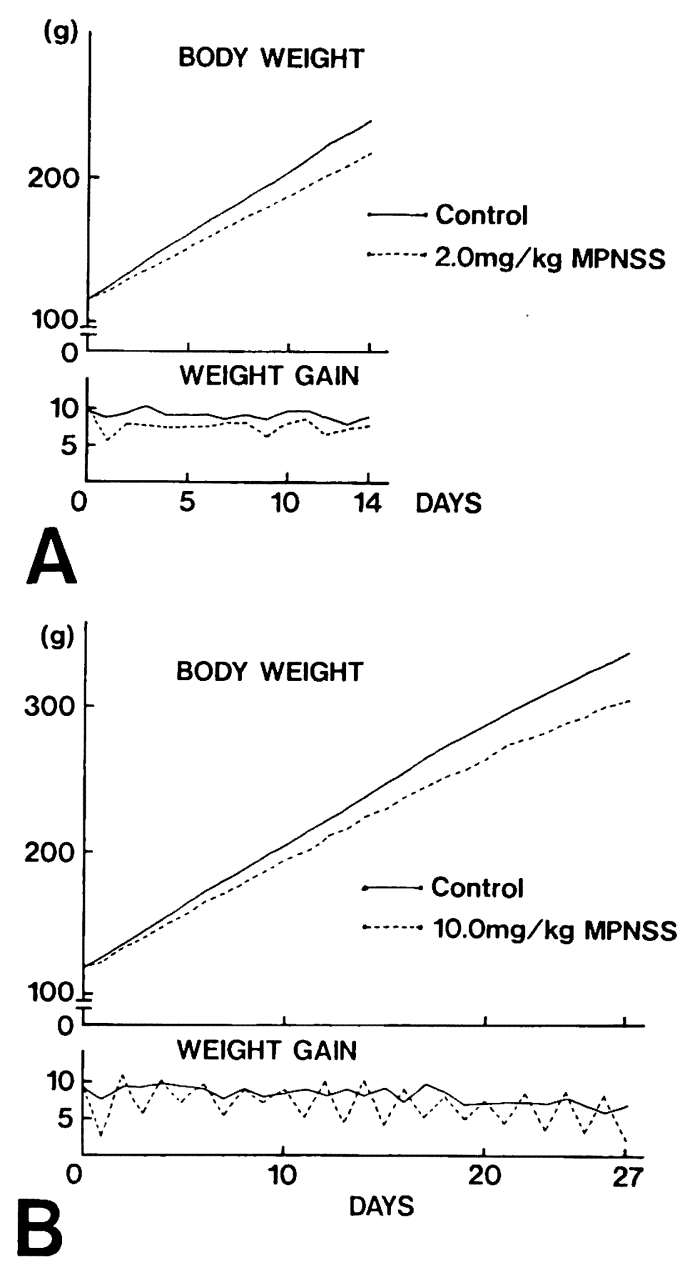

Fig. 5 Changes in the body weight and weight gain per day in the control and MPNSSinjected rats. Final body weights (mean $\pm \mathrm{SD}$ of 10 rats), A : $240.5 \pm 14.6 \mathrm{~g}$ (Control) and $219.1 \pm 15.4 \mathrm{~g}^{\mathrm{a}}$ (MPNSS), B : $339.5 \pm 18.4 \mathrm{~g}$ (Control) and $305.5 \pm 17.7$ $\mathrm{g}^{\mathrm{a}}$ (MPNSS): a : significant difference at $\mathrm{p}<0.01$ (MPNSS vs Control). The mean values are shown in the Figure.

was maintained at a constant but lower level after the 2 nd day in comparison with the control group (Fig. 5-A). On the other hand, in the alternate-day-injection-group, the increment of the body weight reduced gradually (Fig. 5-B), and the weight gain per day markedly decreased in the initial $24 \mathrm{hrs}$ after MPNSS injection and then rapidly recovered in the following $24 \mathrm{hrs}$. This cyclic pattern within $48 \mathrm{hrs}$ was maintained throughout the 
Table 1 Effects of MPNSS on the adrenal weight and the formation of hard tissues.

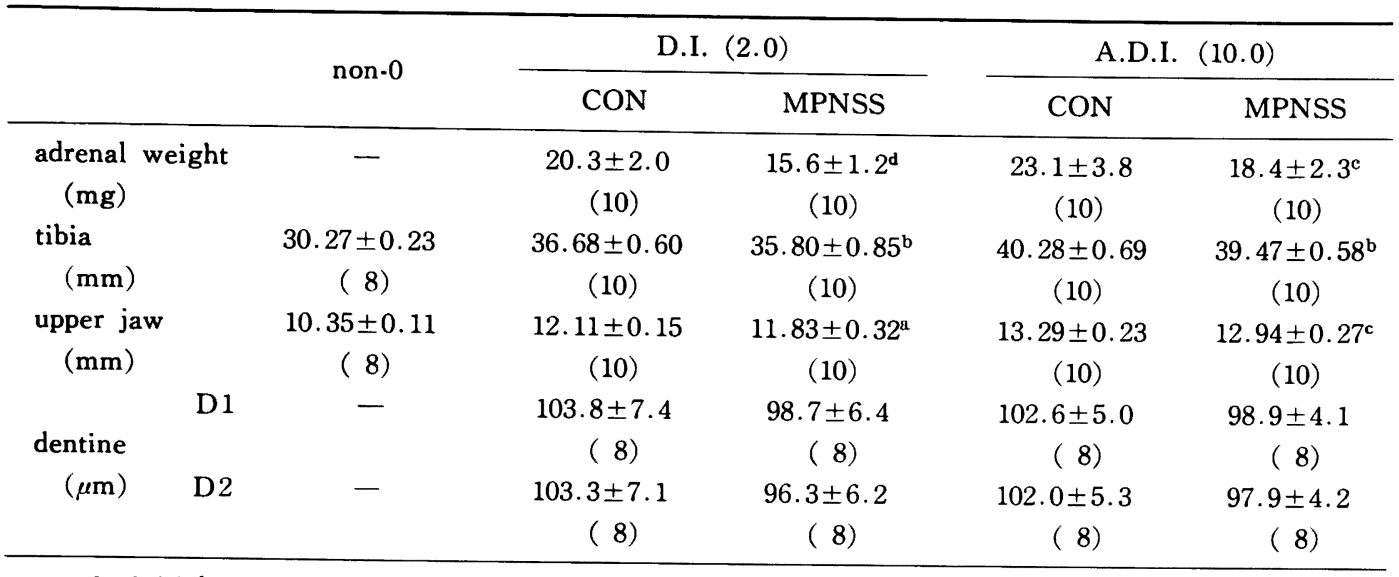

non-0 : initial control at 0 -day.

D.I. (2.0) : Daily injections of MPNSS (2.0mg/kg, i.p., 14 times).

A.D.I. (10.0): Alternate-day injections of MPNSS (10.0 mg/kg, i.p., 14 times).

MPNSS : Methylprednisolone sodium succinate.

CON : age matched control $(0.9 \% \mathrm{NaCl}$ solution, i.p.).

D1: The rate of dentine formation in the initial 6 days.

D2: The rate of dentine formation in the following 6 days.

Values in parentheses are number of animals. Each value represents mean \pm SD. a: Significantly

different from respective controls at $\mathrm{p}<0.05$, b : at $\mathrm{p}<0.02$, $\mathrm{c}:$ at $\mathrm{p}<0.01$ and $\mathrm{d}:$ at $\mathrm{p}<0.001$.

experimental period.

The effect of MPNSS on the weight of adrenal gland is shown in Table 1 . Significant decreases were found in both daily-injection-group $(2.0 \mathrm{mg} / \mathrm{kg}) \quad($ Table $1, \mathrm{p}<0.001)$ and alternate-day injection-group $(10.0 \mathrm{mg} / \mathrm{kg})$ (Table $1, \mathrm{p}<0.01$ ). The adrenal atrophy in both groups suggests that the suppression of the hypothalamic-pituitary-adrenal system occurred following repeated administrations of MPNSS.

The effects of MPNSS on the formation of different types of hard tissues are also shown in Table 1. The longitudinal growth of tibia and the growth of upper jaw were significantly reduced following daily administration of MPNSS in comparison with the control values (Table 1, tibia: $\mathrm{p}<0.02$, upper jaw : $p<0.05)$. In the case of the alternate-day administration of the drug, the growth of both tibia and upper jaw were also significantly reduced (Table 1 , tibia: $\mathrm{p}<$ 0.02 , upper jaw : $p<0.01$ ). As to the rate of dentine formation in the incisor, any significant changes could not be detceted following injections of MPNSS in comparison with the control values, although the aver. age values tended to be retarded (Table 1). These findings suggest that there may be a difference in the sensitivity to the drug between osteoblasts and odontoblasts.

In order to compare the effects of daily and alternate-day administrations of the drug on the growth of tibia and upper jaw, the rate of growth reduction (\%) in the length of each measured site was calculated from the data in Table 1 by Yamada's formula ${ }^{24}$ as follows :

Let $\mathrm{C}$ be the mean value in the final control group, $U$ be the mean value in the initial control group, $M$ be the mean value in the MPNSS group.

Rate of growth reduction $(\%)=\frac{\mathrm{C}-\mathrm{M}}{\mathrm{C}-\mathrm{U}} \times 100$

Using the same formula, the rates of growth reduction in the body weight were also calculated from the data in Fig. 5-A and B. As shown in Table 2, the rates of growth reduction in the daily-injection-group were always greater than those in the alternateday-injection-group in spite of the less dose $(1 / 5)$ in the former.

Both defatted dry weight (D. D. W.) and ash weight (Ash) of tibiae did not show any 
Table 2 Rates of growth reduction (\%) in the lengths of tibia and upper jaw, and the body weight when doses and intervals of the drug administration differed.

\begin{tabular}{lrcc}
\hline & tibia & upper jaw & body weight \\
\hline D.I. (2.0) & 13.7 & 15.9 & 17.5 \\
A.D.I.(10.0) & 8.1 & 119 & 15.6 \\
\hline
\end{tabular}

D.I.(2.0) : Daily injections of MPNSS (2.0 $\mathrm{mg} / \mathrm{kg}$, i.p., 14 times).

A.D.I. (10.0): Alternate-day-injections of MPNSS $(10.0 \mathrm{mg} / \mathrm{kg}$, i.p., 14 times). The values were calculated from the data in Table 1 using the formula described in the text.

significant changes between the two groups. Only the Ash/D. D. W. value in the dailyinjection-group showed a significant increase as compared with the control value (Fig. 6, $\mathrm{p}<0.02$ ).

Microradiographically, the metaphyseal region of the tibia did not show any particular changes in all of the MPNSS-injected-groups as to the trabecular bone volume, the thickness of cortical bone and the width of the epiphyseal plate (data not shown).

Plasma calcium contents were maintained almost at the same level throughout the experimental period and no significant differences were detected between the MPNSS and the control groups. Similar findings were obtained in both daily- and alternate-dayinjection groups. On the other hand, plasma phosphorus contents decreased with time. No significant differences were detected between the MPNSS and control groups except on the 24 th day (Fig. 7, Only the data from the alternate-day-injection group are shown).

\section{Discussion}

Administration of glucocorticoids (GCs) has been known to induce marked weight loss in a dose-dependent manner ${ }^{11}$. In order to reduce this effect, a small dose of MPNSS was used in the present study. Under such an experimental condition, the short-term effect of MPNSS on the growth of hard tissues would be too small to detect the difference exactly. In addition. the graduation of the dial calipers was not so fine. Thus, the total
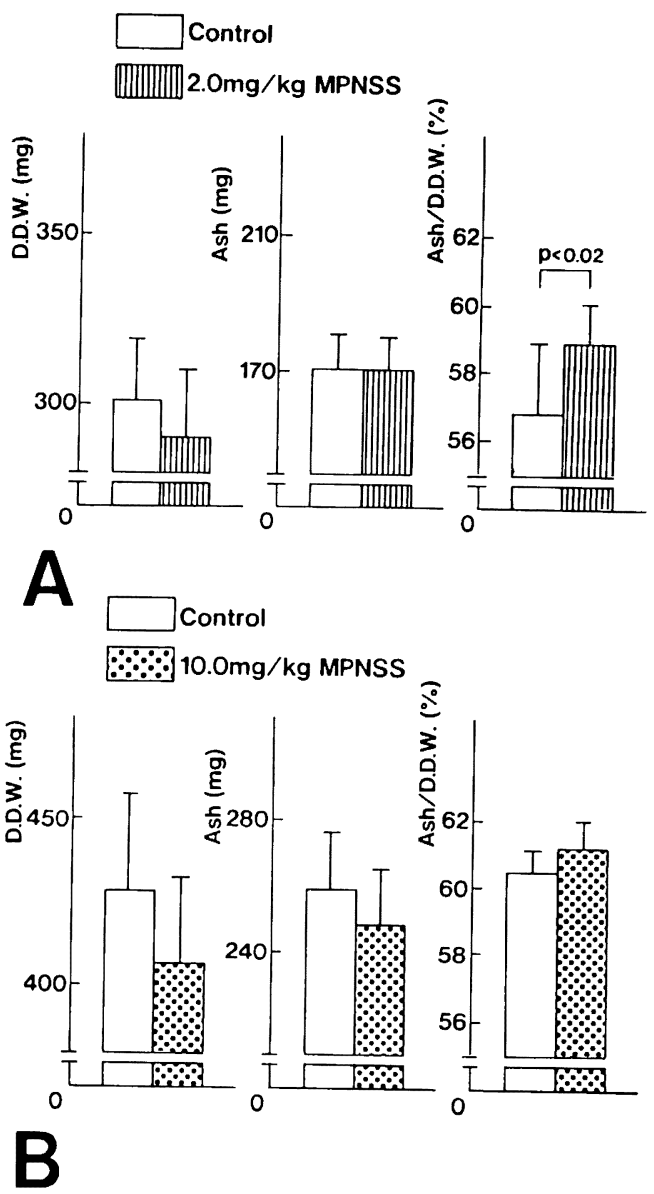

Fig. 6 Effect of MPNSS on the tibia component. A : Daily injections of MPNSS $(2.0 \mathrm{mg} / \mathrm{kg}$, i. p., 14 times), Control $(0.9 \% \mathrm{NaCl}$ solution, i. p., 14 times). B : Alternate-day injections of MPNSS ( $10.0 \mathrm{mg} / \mathrm{kg}$, i. p., 14 times), Control $(0.9 \% \mathrm{NaCl}$ solution, i. p., 14 times). Each value represents mean \pm SD of 10 animals. D. D. W.: Defatted dry weight of tibia, Ash: Ash weight of tibia.

accumulated values throughout the experimental period was measured. As a result, it was possible to detect the inhibition of the longitudinal growth of bone in both the upper jaw and the tibia.

On the other hand, the rate of dentine of dentine formation was not changed siginifcantly following MPNSS administration. The dose used in the present experiment may 


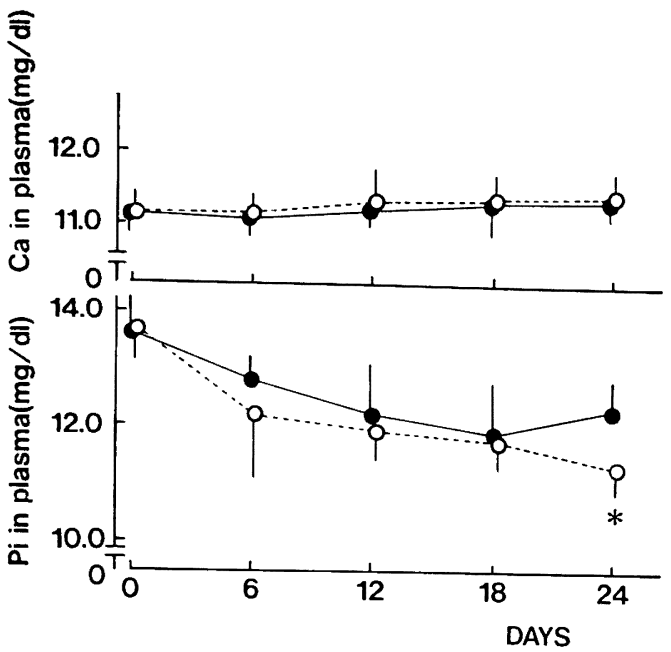

Fig. 7 Effects of MPNSS on the contents of plasma calcium and phosphorus. Each value represents mean $\pm S D$ of 10 animals. Alternate-day injections of MPNSS (O) and Control (o).

* : Significantly different from control at $\mathrm{p}<0.01$.

be too small to suppress the dentine formation because the retardations of matrix formation and calcification of the incisor dentine in the rats have been demonstrated after the administration of a large dose of $\mathrm{GC}^{28)}$.

It has been thought that the side effects of different kinds of GCs are very similar each other, except for the difference in the degrees of the effect. In the previous studies, the suppression of bone growth in the experimental animals has been induced by repeated administrations of high-doses of cortisone acetate to the $\mathrm{rat}^{18-21)}$ and MPNSS to the rabbit ${ }^{22}$. Also in the present experiment, similar suppressive effects were directly demonstrated in the rat after repeated administrations of MPNSS (Table 1).

The mechanism of action on the inhibition of bone growth has been reported to relate with a suppression of the activities of the osteoblast and a direct effect on the bone-cell development ${ }^{5}$. Jee et al. have shown that repeated administrations of cortisol suppressed the osteoprogenitor cell proliferation and inhibited bone formation both dose- and timedependently ${ }^{29}$.

In addition, it has been postulated that the inhibition of the bone growth is due to the acceleration of protein catabolism or the inhibition of the protein synthesis ${ }^{30)}$ which may be supported by our finding on the increase of Ash/D. D. W. of the bone (Fig. 6). An antagonistic effect of GCs on the action of growth hormone may be one of the important factors. Soyka and Crawford ${ }^{31)}$ have demonstrated that the suppression of linear growth by GCs or adrenocorticotropic hormone (ACTH) can be overcome by administration of growth hormone. And also, a decrease in the food consumption following GC-administration $^{11,19,32)}$ may be a cause of the growth retardation.

All of these factors described above may cause the inhibition of bone matrix formation followed by the inhibition of bone growth.

Suppression of new bone formation seems to be a major reason for GC-induced osteoporosis $^{51}$ and also to be one of the main cause of retardation of bone-growth. Although the administration of MPNSS induced the suppression of bone formation (Table 1), osteoporosis could not be detected in the present study. If the suppression of bone formation was accompanied by the activation of bone resorption, osteoporosis would be induced following the administration of MPNSS. Endogenous parathyroid hormone (PTH) may be one of the factors on the acceleration of bone resorption $^{33)}$. It has been postulated that GCs impair intestinal calcium absorption ${ }^{34,35)}$, causing mild hypocalcemia and secondary hyperparathyroidism ${ }^{6,33)}$. Using growing young rats, $\mathrm{Amano}^{36)}$ has demonstrated that the osteoporosis-like change was induced when the animals were only fed on a calcium deficient diet. Hyperparathyroidism might undoutedly be caused under a calcium deficient condition. Disturbance of the calcium homeostasis seems to be one of the essential factors to induce osteoporosis.

The concentrations of plasma calcium and phosphorus did not show any significant changes during the experimental period (Fig.7). And also, the total ash content of tibia, at the end of the experimental period, showed no significant changes between the MPNSSinjected and control groups (Fig. 6). There- 
fore, it is assumed that an essential amount of calcium was absorbed from the intestine and utilized for the bone formation and calcium homeostasis during the experimental period. As a result, the administration of MPNSS might not activate PTH secretion in the present study. This may be a possible reason why osteoporosis was not induced in spite of the retardation of bone formation in the present experiment.

To reduce the side effects of GCs, alternateday administrations of the drug $(48 \mathrm{hrs}$ interval) has been done ${ }^{2)}$ for the clinical treatment $^{371}$ and the animal experiment ${ }^{22}$. The mechanism of such an effect, however, is not yet clear. Also in the present experiment, in spite of a larger dose, inhibitory effects on the bone growth and weight gain seemed to be less in the alternate-day-injection group than in the daily-injection group (Table 2). The weight gain was retarded in the initial $24 \mathrm{hr}$ at each MPNSS injection and recovered to the normal level in the next $24 \mathrm{hr}$ when
MPNSS was injected every other day (Fig. 5-B). The rapid recovery from the weight loss during the intermediate period may be important to reduce the side effects of MPNSS. It is not known whether the retardation of the side effects of GCs is parallel with that of the therapeutic effects of the same drug. It is difficult to answer that question from the present experimental results.

In conclusion, the present study showed a direct inhibitory effect of MPNSS on the bone growth in growing young rats. It is suggested that a larger dose of GCs could be given more effectively by the alternate-day administration with less side effects.

\section{Acknowledgements}

Authors thank prof. M. Chiba, Tsurumi University, for his kind advice on the statistical analyses, and also wish to thank Dr. S. Mataki for his valuable suggestions and kindness in preparing this manuscript.

抄録：成長期ラットの硬組織成長及びその性状に及ぼすコハク酸メチルプレドニゾロンナトリウム (MP NSS) の影響を検索する目的で本研究を行った。生後 5 週齢ラットに異なる用量の MPNSS (10.0mg/ kg 隔 日投与， $2.0 \mathrm{mg} / \mathrm{kg}$ 連日投与）をそれぞれ14回腹腔内注射し，対照群には生理食塩液を投与した。体重は毎 日測定し，屠殺後，湿性副腎重量測定，ノギスによる上顎骨（diastema）及び脛骨の長さ測定，硬組織内時 刻描記法による下顎切歯象牙質の形成量測定，脛骨の脱脂乾燥重量と灰化重量測定などを行った。さらに Ca 代謝に及ぼす影響を知る目的で血漿中の $\mathrm{Ca}$ 及び P量を測定した。その結果, MPNSS 投与により両群とも に体重増加抑制, 副腎の萎縮及び骨の成長抑制が認められた。しかし脛骨骨端部の顕微X線像からは骨粗鬆 症の所見は認められなかった。また，血漿 $\mathrm{Ca}, \mathrm{P}$ 量も変動しなかった。各種計測值の比較により，成長抑制 の程度は連日投与法の方が隔日投与法より大きいことが確認できた。以上の結果から MPNSS 連続投与によ

り，Ca 代謝異常を伴うことなく成長期ラットの骨成長や体重増加が抑制される事が確認された。またこれら の副作用は隔日投与を行うことによって効果的に軽減される可能性が示唆された。

\section{References}

1) Haynes, R. C. Jr. and Murad, F. : Adrenocorticotropic hormone; adrenocortical steroids and their synthetic analogs; inhibitors of adrenocortical steroid biosynthesis. In : Goodman and Gilman's The Pharmacological Basis of Therapeutics. (Gilman, A. G., Goodman, L. S., Rall, T. W. and Murad, F. eds.) 7 th edn. pp. 1459-1489, Macmillan Publishing Company, New York, 1985.

2) Axelrod, L. : Side effects of glucocorticoid therapy. In : Anti-inflammatory Steroid Action. Basic and Clinical Aspects. (Schleimer,
R. P., Claman, H. N. and Oronsky, A. eds.) 1 st edn. pp. 377-408, Academic Press, Inc., San Diego, 1989.

3) Rude, R. K. and Singer, F. R. : Hormonal modifiers of mineral metabolism other than parathyroid hormone, vitamin $\mathrm{D}$, and calcitonin. In: Disorders of Mineral Metabolism, Vol. 2, Calcium Physiology. (Bronner, F. and Coburn, J. W. eds.) 1 st edn. pp. 481-556, Academic Press, Inc., New York, 1982.

4) Gennari, C.: Glucocorticoids and bone. In : Bone and Mineral Research, Vol. 3. (Peck, W.) 1 st edn. pp. 213-231, Elsevier, 
Amsterdam, 1985.

5) Smith, R.: Corticosteroids and osteoporosis. Thorax 45 : 573-578, 1990.

6) Hahn, T. J. Halstead, L. R., Teitelbaum, S. L. and Hahn, B. H.: Altered mineral metabolism in glucocorticoid-induced osteopenia. J. Clin. Invest. 64 : 655-665, 1979.

7) Baylink, D. J.: Glucocorticoid-induced osteoporosis. New. Engl. J. Med. 309 : 306308, 1983.

8) Lindgren, J. U. and DeLuca, H. L. : Oral 1, $25(\mathrm{OH})_{2} \mathrm{D}_{3}$ : An effective prophylactic treatment for glucocorticoid osteopenia in rats. Calcif. Tissue Int. 35: 107-110, 1983.

9) Meunier, P. J. and Bressot, C. : Endocrine influences on bone cells and bone remodeling evaluated by clinical histomorphometry. In : Comprenhensive Endocrinology: Endocrinology of Calcium Metabolism. (Parsons, J. A. eds.) 1 st edn. pp. 445-465, Raven Press, New York, 1982.

10) Jee, W. S. S., Park, H. Z., Roberts, W. E. and Kenner, G. H. : Corticosteroid and bone. Am. J. Anat. 129 : 477-479, 1970.

11) Tonelli, G., Partridge, R. and Ringler, I. : Body and muscle weight depressing effects and thymolytic potencies of glucocorticoids in the rat. Proc. Soc. Exp. Biol. Med. 119 : 136-142, 1965.

12) Blodgett, F. M., Burgin, L., Iezzonni, D., Gribetz, D. and Talbot, N. B. : Effects of prolonged cortisone therapy on the statural growth, skeletal maturation and metabolic status of children. New. Engl. J. Med. 254 : 636-641, 1956.

13) Falliers, C. J., Tan, L. S., Szentivanyi, J., Jorgensen, J. R. and Bukantz, S. C. : Childhood asthma and steroid therapy as influences on growth. Am. J. Dis. Child. 105 : 127-137, 1963.

14) Van Metre, T. E. Jr., Niermann, W. A. and Rosen, L. J.: A comparison of the growth suppressive effect of cortisone, prednisone, and other adrenal cortical hormones. J. Allergy 31:531-542, 1960.

15) Parmer, L. G., Katonah, F. and Angrist, A. A.; Comparative effects of ACTH, cortisone, corticosterone, desoxycorticosterone, pregnenolone on growth and development of infant rats. Proc. Soc. Exp. Biol. Med. 77 : 215-218, 1951.

16) Field, E. J. : Effect of cortisone on the neonatal rat. Nature $174: 182,1954$.

17) Moss, M. L.: Morphological changes in the growing rat skull following administration of cortisone acetate. Proc. Soc. Exp. Biol.
Med. 89 : 648-650, 1955.

18) Johannessen, L. B. : Effects of cortisone on dentioogenesis in mandibular first molars of albino rats. Arch. Oral Biol. 9 : 421-434, 1964.

19) Johannessen, L. B., Davidovitch, Z. and Blackey, W. E. : Effects of cortisone and of caloric restriction on skeletogenesis in immature rats. Arch. Oral Biol. 11 : 31-39, 1966.

20) Kukreja, S. C., Bowser, E. N., Hargis, G. K., Henderson, W. J. and Williams, G. A. : Mechanisms of glucocorticoid-induced osteopenia: Role of parathyroid glands. Proc. Soc. Exp. Biol. Med. 152 : 358-361, 1976.

21) Simmons, D. J. and Kunin, A. S. : Autoradiographic and biochemical investigations of the effect of cortisone on the bones of the rat. Clin. Orthop. 55 : 201-215, 1967.

22) Sheagren, J. N., Jowsey, J., Bird, D. C., Gurton, M. E. and Jacobs, J. B. : Effect on bone growth of daily versus alternate-day corticosteroid administration : an experimental study. J. Lab. Clin. Med. 89 : 120-130, 1977.

23) Perault-Staub, A. M., Staub, J. F. and Milhanud, G.: A new concept of plasma calcium homeostasis in the rat. Endorcinology 95 : 480-484, 1974.

24) Yamada, S. : Inhibitory action of sodium salicylate on the growth of upper jaw and tibia in rats. Jpn. J. Pharmacol. 27 : 303-310, 1977.

25) Ogura, H.: Chronological-labelling method for hard tissues, In: Research Methods of Teeth, Histology and Chemistry. (Suga, S., Takuma, S. and Sasaki, S., eds.) 1 st edn. pp. 157-184, Ishiyaku Publishers Inc., Tokyo, 1973. (in Japanese).

26) Trudeau, D. L. and Freier, E. F.: Determination of calcium in urine and serum by atomic absorption spectrophotometry (AAS). Clin. Chem. 13 : 101-104, 1967.

27) Chen, P. S. Jr., Toribara, T. Y. and Warner, H. : Microdetermination of phosphorus. Anal. Chem. 28 : 1756-1758, 1956.

28) Matsumoto, S. : Formation of hard tissue, In: Anti-inflammatory Drug Therapy in the Dental Clinic. (Ito, H., Maizumi, H. and Ogura, Y. eds.) 1 st edn. pp. 240-251, Ishiyaku Publishers Inc., Tokyo, 1981. (in Japanese).

29) Jee, W. S. S., Roberts, W. E., Park, H. Z., Julian, G. and Kramer, M. : Interrelated effects of glucocorticoid and parathyroid hormone upon bone remodeling. In: Calcium, Parathyroid Hormone and Calcitonins, 
Proceeding of the 4 th Parathyroid Conference. (Talmage, R. V. and Munson, P. L. eds.) pp. 430-439, Excerpta Medica 1972.

30) Mclean, F. C. and Urist, M. R. : Corticotropin (ACTH) and adrenal cortical steroids. In: Bone, Fundamentals of the Physiology of Skeletal Tissue. $3 \mathrm{rd}$ edn. pp. edn. pp. 124-126, The University of Chicago Press, Chicago and London, 1968.

31) Sokya, L. F. and Crawford, J. D.: Antagonism by cortisone of the linear growth induced in hypopituitary patients and hypophysectomized rats by human growth hormone. J. Clin. Endocrinol. Metab. 25 : 469-475, 1965.

32) Winter, C. A., Silber, R. H. and Stoerk, H. C.: Production of reversible hyperadrenocortinism in rats by prolonged administration of cortisone. Endocrinology 47:60-72, 1950.

33) Williams, G. A., Peterson, W. C., Bowser, E. N., Henderson, W. J., Hargis, G. K. and Martinez, N. J.: Interrelationship of parathyroid and adrenocortical function in calcium homeostasis in the rat. Endocrinology 95 : 707-712, 1974.

34) Lukert, B. P., Stanbury, S. W. and Mawer, E. B. : Vitamin D and intestinal trasport of calcium : Effects of prednisolone. Endocrinology 93 : 718-722, 1973.

35) Kimberg, D. V., Baerg, R. D., Gershon, E. and Graudusius, R. T.: Effect of cortisone treatment on the active transport of calcium by the small intestine. J. Clin. Invest. 50 : 1309-1321, 1971.

36) Amano, H.: A histomorphometric analysis of the alveolar bone resorption process in calcium-deficient rats. Jpn. J. Oral Biol. 31 : 404-416, 1989.

37) Ackerman, G. L. and Nolan, C. M. : Adrenocortical responsiveness after alternateday corticosteroid therapy. New. Engl. J. Med., 278 : 405-409, 1968. 